\title{
THE TRIBE ACUTALINI FOWLER (HOMOPTERA, MEMBRACIDAE, SMILIINAE): NEW GENERA, NEW SPECIES AND SOME NOMENCLATURAL CHANGES ${ }^{1}$
}

\begin{abstract}
The tribe Acutalini Fowler is redescribed as well as the genera Acutalis Fairmaire, Euritea Stål, and Thrasymedes Kirkaldy. The following new taxa and nomenclatural changes are presented: Thrasymedes mexicana sp.n. (from Mexico, Oaxaca); Bordonia gen.n., with B. venezuelana sp.n. (type-species) (from Venezuela, Portachuelo), B. clypeata sp.n. (from Colombia, Cuesta Boba), B. majuscula sp.n. (from Venezuela, Portachuelo), and Cornutalis gen.n., with C. cauca sp.n. (type-species) (from Colombia, Cauca), and C. valida sp.n. (from Ecuador, Sto. Domingo). Acutalis fusconervosa Fairmaire, 1846 = Horiola venosa Walker, 1858, syn.n.; Euritea munda $($ Walker, 1858) = Stictolobus nitidus Funkhouser, 1940, syn.n.; Bordonia nigricosta (Goding, 1926), comb.n.; Bordonia virescens (Funkhouser, 1940), comb.n.. One species is transferred to Smiliinae-Ceresini: Tapinolobus curvispina (Walker, 1858), comb.n. (formerly in Thrasymedes) $=$ Tapinolobus fasciatus Sakakibara, 1969, syn.n.; another one is transferred to Darninae-Cymbomorphini: Eumela darnioides (Walker, 1858), comb.n. (formerly in Euritea).

KEY WORDS. Homoptera, Membracidae, Smiliinae, taxonomy
\end{abstract}

Albino M. Sakakibara ${ }^{2}$

The tribe Acutalini (sensu DeITz 1975: 88) includes the genera Acutalis Fairmaire, Euritea Stål, and Thrasymedes Kirkaldy. The diagnostic characters of this group given by DEITZ (1975), are: pronotum not concealing forewings; forewings with $\mathrm{R}, \mathrm{M}$, and $\mathrm{Cu}$ separate near base, $\mathrm{R} 2+3$ present as distinct branch of $\mathrm{R}$, with one $\mathrm{r}$ and one $\mathrm{m}$-cu crossveins; hindwing with one $\mathrm{r}-\mathrm{m}$ crossvein, marginal vein $\mathrm{R} 2+3$ distinct.

Among the material belonging to Bordón's Collection (Venezuela), were found five new species that do not fit well in the Acutalini, as defined above. They present two $\mathrm{m}$-cu crossveins and no $r$ in the forewings. Two of them also present supra-humeral horns. Therefore, the tribe Acutalini Fowler is here redefined to include these new members.

\section{Acutalini Fowler, 1895}

Acutalini Fowler, 1895: 87. - Metcalf \& Wade, 1965: 1141. - Deitz, 1975: 88.

Pronotum low, metopidium convex, supra-humeral horns present or not; posterior process sometimes distinctly acuminate, not reaching tips of tegmina; surface smooth, shining or roughly punctured; lateral margins almost always

1) Contribuição número 931 do Departamento de Zoologia, Universidade Federal do Paraná.

2) Departamento de Zoologia, Universidade Federal do Paraná. Caixa Postal 19020, 81531-990 Curitiba, Paraná, Brasil. Bolsista do CNPq. 
longitudinally impressed. Tegmina entirely exposed; $\mathrm{R}, \mathrm{M}$, and $\mathrm{Cu}$ separated near base; five apical cells, the third peciolate; 0 or $1 \mathrm{r}$ crossvein (Figs 24, 25); 1 or 2 $\mathrm{m}$-cu crossveins (Figs 24, 25 and 26,27). Wings with four apical cells; r-m crossvein present (Fig. 24).
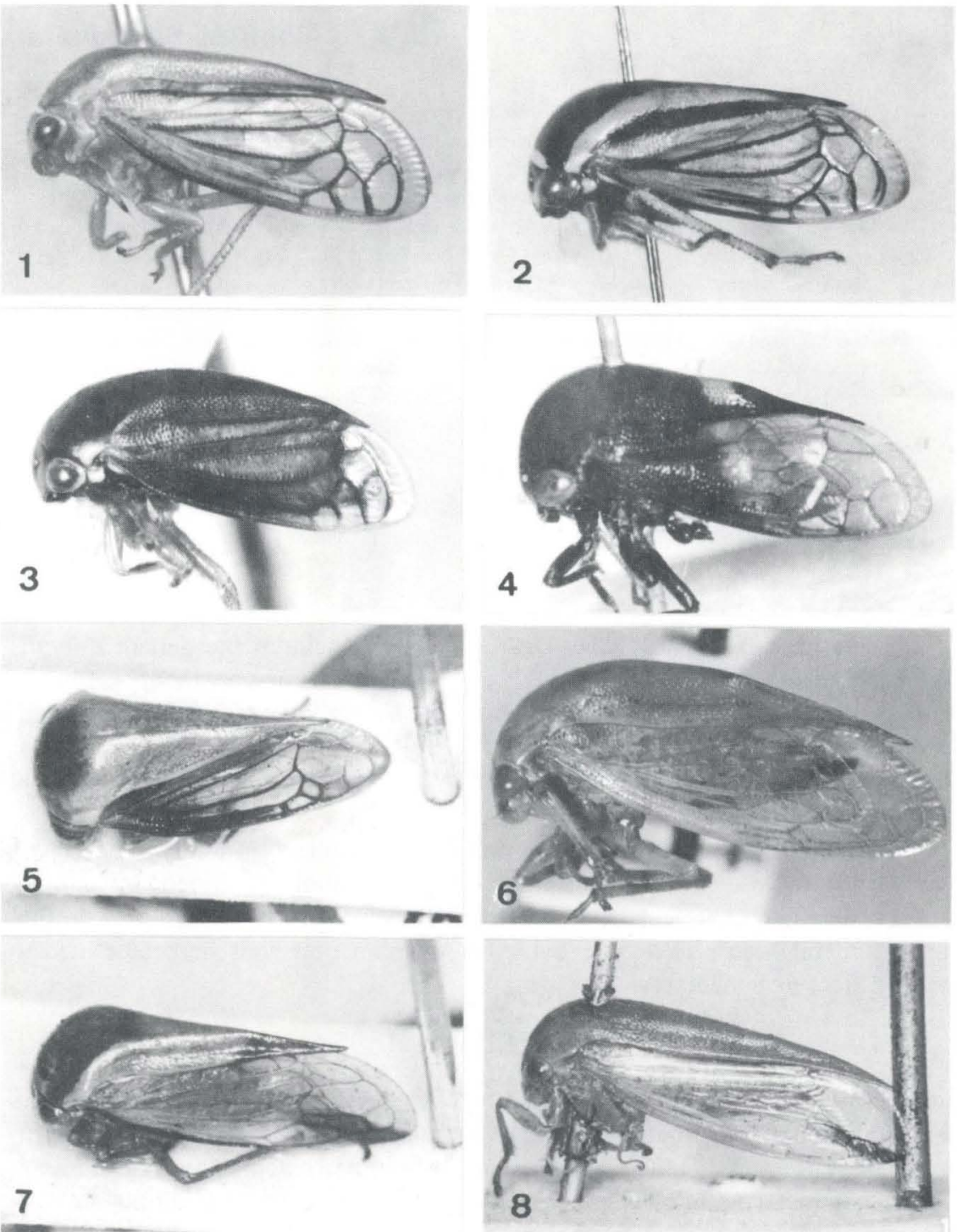

Figs 1-8. (1) Acutalis fusconervosa; (2) Acutalis nigrinervis; (3) Acutalis tartarea; (4) Euritea munda, Lectotype; (5) Thrasymedes dubia, Lectotype; (6) Thrasymedes pallescens; (7) Thrasymedes variata, Lectotype; (8) Thrasymedes walkeri, Holotype. 


\section{Key to genera of Acutalini}

1. Tegmina without discoidal cells (Fig. 24) ................... Acutalis

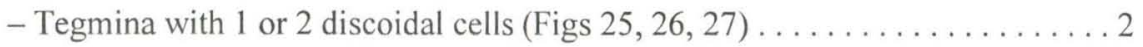

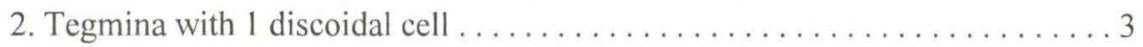

- Tegmina with 2 discoidal cells $(\mathrm{R} 2+3$ and $\mathrm{M}) \ldots \ldots \ldots \ldots \ldots$ Euritea

3. With discoidal cell R2+3 (Fig. 25) .................. Thrasymedes

- With discoidal cell M (Fig. 26) . . . . . . . . . . . . . . . . . . . . . . 4

4. Without supra-humeral horns . . . . . . . . . . . . . Bordonia gen.n.

- With supra-humeral horns . . . . . . . . . . . . . . . . Cornutalis gen.n.

\section{Acutalis Fairmaire, 1846}

Acutalis Fairmaire, 1846: 496 (Type species: Acutalis fusconervosa Fairmaire, 1846, subseq. desig.). Caldwell, 1949: 497. - Metcalf \& Wade, 1965: 1144. - Kopp \& Yonke, 1973: 235. - Deitz, 1975: 88.

Diagnosis. Pronotum smooth, shining, apex acute (Fig. 1-3). Tegmina with $\mathrm{R}, \mathrm{M}$, and $\mathrm{Cu}$ separate from near base to beyond middle; without discoidal cells; five apical cells (Fig. 24).

Description. Head triangular, smooth and shining, about three times as wide as long; superior margin sinuous; supra-antennal ledges with margins arched, in a continuous line with that of clypeus; this triangular, in the same plan of vertex. Eyes ovate. Ocelli slightly nearer to eyes and superior margin than to each other. Pronotum low, smooth, shining, extended posteriorly to about the end of fifth apical cell of tegmina, terminal portion tectiform and with acute apex; lateral margins longitudinally impressed; punctuation more visible after humeral angles. Tegmina entirely exposed; veins R, M, and Cu separated near base and only branched beyond middle; without discoidal cells ( $0 \mathrm{r}$ crossvein and $1 \mathrm{~m}$-cu crossvein); five apical cells, the third peciolate, larger than the fifth. Wings with four apical cells; $r-m$ crossvein present. Male pygofer with lateral plates well developed; subgenital plate elongate, navicular, apically rounded and notched; aedeagus subcilindrical, curved upward and with microdenticules on dorsal surface near apex; styles strongly recurved and apically pointed.

Comments. This genus is characterized by the tegmina presenting $\mathrm{R}, \mathrm{M}$, and $\mathrm{Cu}$ separate and devoid of discoidal cells, i.e., with no $\mathrm{r}$ and with only one $\mathrm{m}$-cu crossvein.

The following species belong to this genus:

\section{Acutalis fusconervosa Fairmaire, 1846}

Figs $1,24,28$

Acutalis fusconervosa Fairmaire, 1846: 498 (Type loc.: Colombia). - Caldwell, 1949: 498. - Metcalf \& Wade, 1965: 1147. - Deitz, 1975: 88.

Horiola venosa Walker, 1858: 76 (Type loc.: unknown). - Funkhouser, 1927: 170. - Metcalf \& Wade, 1965: 881 [= Harmonides reticulata $($ Fabr.)]. - Broomfield, 1971: 384. Syn.n. 
Comments. Head and pronotum light-brown; lateral margins, including humeral angles, yellowish. Tegmina hyaline, veins dark-brown, limbus slightly infuscate. As Fowler (1895) comments, this species is extremely variable in regarding its color, going from light-cataneous to almost black.

\section{Acutalis nigrinervis Fowler, 1895}

Fig. 2

Acutalis nigrinervis Fowler, 1895: 114 (Type loc.: Mexico). -Metcalf \& Wade, 1965: 1148. Broomfield, 1971: 363.

Comments. Almost entirely black, with yellow stripe on head, metopidium above the head and sides of pronotum just above the lateral margins, extending from behind the eyes up to near the tip of posterior process. Tegmina hyaline with veins black.

\section{Acutalis tartarea (Say, 1830)}

Figs 3

Membracis tartarea Say, 1830: 242 (Type loc.: USA).

Acutalis tartarea; Caldwell, 1949: 498. - Kopp \& Yonke, 1973: 235. - Metcalf \& Wade, 1965: 1150. Membracis semicrema Say, 1830: 242 (Type loc.: USA). - Tsai \& Kopp, 1980: 183 (syn.).

Acutalis tartarea var. semicrema; Caldwell, 1949: 498. - Kopp \& Yonke, 1973: 235.

Acutalis semicrema; Metcalf \& Wade, 1965: 1148.

Acutalis inornata Ball, 1905: 119 (Type loc.: USA). - Tsai \& Kopp, 1980: 183. - Metcalf \& Wade, 1965: 1147.

Acutalis tartarea var. inornata; Caldwell, 1949: 498. - Kopp \& Yonke, 1973: 235.

Comments. The pronotum in Acutalis tartarea is almost entirely black, except for a small yellow area behind the eyes. The tegmina are also black with the apical portion hyaline. Acutalis semicrema presents the pronotum yellow with a large black patch on metopidium that extends to dorsum, and the tegmina are hyaline. Caldwell (1949), studying the male genitalia, concluded that A. semicrema, A. nigrinervis, and $A$. inornata were color variations of $A$. tartarea, considering them, therefore, as mere varieties. Kopp \& Yonke (1973) confirmed the existence of these variations collecting specimens of different color patterns in the same locality, in Missouri, and then maintained the three varieties. Tsai \& Kopp (1980) verified the same and put $A$. semicrema and $A$. inornata in the synonymy of $A$. tartarea. On the other hand, A. nigrinervis Fowler is considered here a distinct species, for a while, because the available material is not sufficient to comprove whether it is a variety or not.

\section{Euritea Stål, 1867}

Phacusa (Euritea) Stål, 1867: 552 (Type species: Phacusa (Euritea) personata Stål, 1869; subseq. desig.).

Euritea; Fowler, 1895: 87. - Metcalf \& Wade, 1965: 1142. - Deitz, 1975: 89.

Diagnosis. Pronotum smooth and shining (Fig. 4); tegmina with two discoidal cells, the external one (R2+3) as wide as long and somewhat oblique to costal margin (Fig. 27). 
Description. Head triangular, smooth and shining, about three times as wide as long; superior margin sinuous; supra-antennal ledges with margins arched, in a continuous line with that of clypeus; this triangular, in the same plan of vertex. Eyes ovate. Ocelli slightly nearer to eyes and superior margin than to each other. Pronotum low, smooth, shining, extended posteriorly to about the end of fifth apical cell of tegmina, terminal portion tectiform and with acute point; lateral margins longitudinally impressed; punctuation more visible after humeral angles. Tegmina entirely exposed; veins R, M, and Cu separate near base; with two discoidal cells ( $1 \mathrm{r}$ crossvein and $2 \mathrm{~m}$-cu crossveins); five apical cells, the third peciolate, larger than the fifth. Wings with four apical cells; $r-m$ crossvein present.

Comments. This genus is very close to Acutalis in the general appearance, but differs by having two discoidal cells in the tegmina, the external one $(\mathrm{R} 2+3)$ more or less diamond-shaped.

The following species belong to this genus:

\section{Euritea munda (Walker, 1858)}

Fig. 4

Parmula munda Walker, 1858: 152 (Type loc.: Mexico).

Euritea munda; Metcalf \& Wade, 1965: 1143.

Phacusa (Euritea) nigripes Stål, 1869: 248 (Type loc.: Mexico), -Metcalf \& Wade, 1965: 1143.

Stictolobus nitidus Funkhouser, 1940: 284 (Type loc.: Peru). -Metcalf \& Wade, 1965: 820. Syn.n.

Comments. Head, pronotum, legs and basal half of tegmina, dark-brown. Posterior process with a yellowish patch before apex.

\section{Euritea personata (Stål, 1869)}

Phacusa (Euritea) personata Stål, 1869: 247 (Type loc.: Colombia, Bogota).

Euritea personata; Metcalf \& Wade, 1965: 1143.

Euritea capitata Buckton, 1902. - Metcalf \& Wade, 1965: 1144.

Comments. According to Stål, this species is entirely yellow, except costal margin of tegmina, black.

\section{Thrasymedes Kirkaldy, 1904}

Phacusa Stål, 1864: 72 (Type species: Phacusa flavomarginata Stål, 1864; Monotypy). (Preoc.) Thrasymedes Kirkaldy, 1904: 279 (nom.n.); Metcalf \& Wade, 1965: 1153. - Deitz, 1975: 89.

Diagnosis. Pronotum smooth, shining, low and convex or somewhat tectiform (Fig. 5-8). Tegmina with $\mathrm{R}, \mathrm{M}$, and $\mathrm{Cu}$ separate from near base to beyond middle; with one discoidal cell $(\mathrm{R} 2+3)$, frequently quadrangular, and about twice longer than wide (Fig. 25).

Description. Head triangular, smooth and shining, about three times wider than long; superior margin sinuous; supra-antennal ledges with margins slightly sinuous, in a continuous line with that of clypeus; this triangular, with tip rounded, in the same plan of vertex. Eyes ovate, not projected laterally. Ocelli equidistant from each other and to eyes, nearer to superior margin. Pronotum low, smooth, 
shining, extended posteriorly almost to the tips of tegmina, terminal portion tectiform and pointed; lateral margins longitudinally impressed; punctuation more visible after humeral angles. Tegmina entirely exposed; veins $\mathrm{R}, \mathrm{M}$, and $\mathrm{Cu}$ separated near base and only branched beyond middle; with one discoidal cell (R2+3) quadrangular, about twice longer than wide; $1 \mathrm{r}$ and $1 \mathrm{~m}$-cu crossveins; five apical cells, the third petiolated, smaller than the fifth. Wings with four apical cells; $\mathrm{r}-\mathrm{m}$ crossvein present.

Comments. This genus differs from Euritea in presenting only one discoidal cell (R2+3), which is almost always quadrangular, and longer than wide. The pronotum is slightly longer, extending to just beyond the end of vein $\mathrm{M} 3+4$ of tegmina.

The following species belong to this genus:

\section{Thrasymedes dubia (Fowler, 1895), sp. reval.}

Fig. 5

Phacusa dubia Fowler, 1895: 112 (Type loc.: Guatemala).

Thrasymedes dubia; Funkhouser, 1927: 232. - Metcalf \& Wade, 1965: 1155 (= T. variata Fowler) (error).

Comments. This species is very close to $T$. variata Fowler but differs by the infuscate basal portion and costal margin of tegmina; the discoidal cell is more or less diamond-shaped like that in Euritea. The pronotum is yellowish-brown with a large spot over the metopidium.

\section{Thrasymedes flavomarginata (Stål, 1864)}

Phacusa flavo-marginata Stål, 1864: 72 (Type loc.: Mexico).

Thrasymedes flavomarginata; Metcalf \& Wade, 1965: 1154.

Comments. This species is distinguished by the yellow lateral margins of pronotum and dark basal half of tegmina.

\section{Thrasymedes pallescens (Stål, 1869)}

Fig. 6

Phacusa pallescens Stål, 1869: 247 (Type loc.: Mexico).

Thrasymedes pallescens; Metcalf \& Wade, 1965: 1154.

Phacusa major Fowler, 1895: 111 (Type loc.: Guatemala). - Metcalf \& Wade, 1965: 1155.

Comments. This species is very similar to T. walkeri Metcalf \& Wade; the pronotum is more robust and the tegmina are hyaline and immaculate.

\section{Thrasymedes variata (Fowler, 1895)}

Fig. 7

Phacusa variata Fowler, 1895: 111 (Type loc.: Mexico).

Thrasymedes variata; Metcalf \& Wade, 1965: 1155.

Comments. In comparison with $T$. dubia Fowler, this species presents the pronotum dark-brown interrupted in the middle by a large yellowish band; tegmina hyaline with a distinct oblique infuscate area at the apex, or sometimes absent. 


\section{Thrasymedes walkeri Metcalf \& Wade, 1865}

Fig. 8

Darnis lineola Walker, 1858: 146 (Type loc.: Mexico); (preoc.).

Thrasymedes lineola; Funkhouser, 1927: 232.

Thrasymedes walkeri Metcalf \& Wade, 1965: 1156 (nom.n.).

Comments. This species is very characteristic presenting the pronotum relatively low and elongate, entirely yellowish-brown; tegmina with an oblique infuscate patch at the apex.

\section{Thrasymedes mexicana sp.n.}

Fig. 9

Diagnosis. Pronotum yellowish-brown, smooth and shining; posterior process tectiform, more elevated above abdomen.

Measurements (in mm). Female. Total length 8.40; length of pronotum 7.20; width of head 3.04; width between humeral angles 3.00.

Description. Holotype female. General color yellowish-brown. Head smooth and shining, triangular, less than three times wider than long; superior margin slightly sinuous; eyes ovate, not produced laterally; ocelli situated on an imaginary line that passes through center of eyes, equidistant from each other and to eyes and nearer to superior margin; supra-antennal ledges with margins slightly sinuous and with contour line continuing with that of clypeus; clypeus more or less diamondshaped, in the same plan of vertex. Pronotum smooth and shining; metopidium wide and convex; posterior process tectiform, apex acute, extended to just beyond the fifth apical cell of tegmina, elevated above abdomen; median carina well marked behind dorsal elevation; humeral angles obtuse; sides between eyes and humerus deeply concave.

Male unknown.

Material examined. Holotype female labeled "Mexico: Oaxaca, $12 \mathrm{Km} / \mathrm{N}$. Oaxaca City, hwy 175/ 1900m, 22.IX.1990/leg. R. Baranowski". "Beating flowers and/ shrubs, tropical/ montane forest".

Comments. This species is very different from others by having the posterior process elevated above abdomen in a rounded crest and distinctly tectiform.

\section{Bordonia gen.n.}

\section{Type species: Bordonia venezuelana sp.n.}

Diagnosis. Pronotum low, convex, smooth and shining, posterior process acute (Figs 10-18). Tegmina with two m-cu crossveins (Fig. 26).

Description. Head triangular, smooth and shining, about three times as wide as long; superior margin sinuous; supra-antennal ledges with margins slightly sinuous, in a continuous line with that of clypeus; this somewhat quadrangular,in the same plan of vertex. Eyes ovate, not projected laterally. Ocelli equidistant from each other and to eyes, nearer to superior margin. Pronotum low, convex, smooth, 
shining, extended posteriorly to just little beyond the tip of clavus, terminal portion tectiform and with acute point; lateral margins longitudinally impressed; punctuation more visible after humeral angles. Tegmina entirely exposed; veins R, M, and $\mathrm{Cu}$ separated near base, with one discoidal cell ( $2 \mathrm{~m}$-cu crossveins); five apical cells, the third peciolate, slightly larger than the fifth. Wings with four apical cells; r-m crossvein present. Male pygofer with lateral plates distinct; subgenital plate elongate, apically rounded; aedeagus subcilindrical, provided with two or a series of minute denticules on dorsal surface near apex; styles recurved, truncate and sometimes with a sharp external angle.

Comments. This genus resembles Acutalis but differs by the presence of two m-cu crossveins.

Derivation. The genus is dedicated to C. Bordón.
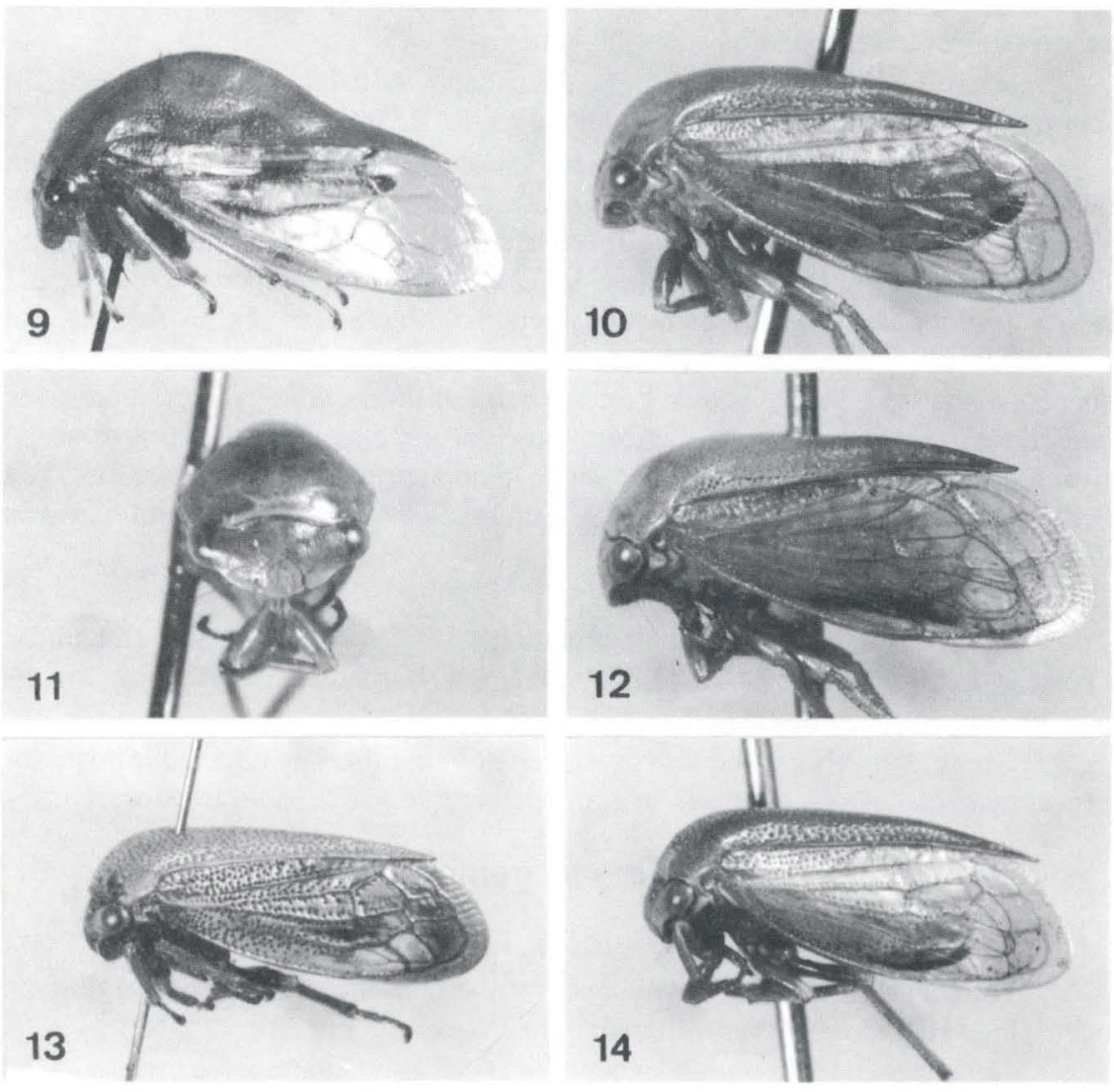

Figs 9-14. (9) Thrasymedes mexicana sp.n., Holotype; (10-11) Bordonia venezuelana sp.n., Holotype female; (12) idem, male; (13) Bordonia clypeata sp.n., male; (14) idem, Holotype female. 


\section{Bordonia venezuelana sp.n.}

Figs $10-12,31$

Diagnosis. Pronotum yellowish-brown, low, convex, smooth and shining.

Measurements (in mm). Female/male. Total length 6.40/6.20; length of pronotum 5.28/5.00; width of head 2.32/2.20; width between humeral angles $2.32 / 2.56$.

Description. Holotype female. Pronotum yellowish-brown; abdomen orange-yellow with undersurface black. Head smooth and shining, triangular, about three times wider than long; superior margin sinuous; eyes ovate, not produced laterally; ocelli situated on an imaginary line that passes through center of eyes, equidistant from each other and from eyes and nearer to superior margin; supra-antennal ledges with margins slightly sinuous and with contour line continuing with that of clypeus; clypeus more or less quadrangular, apex rounded, in the same plan of vertex. Pronotum low, convex, smooth, shining, extended posteriorly in a sharp pointed process, terminating beyond apex of clavus, about middle of fifth cell of tegmina; median carina absent; lateral margins, after humeral angles, distinctly impressed longitudinally. Tegmina with $\mathrm{R}, \mathrm{M}$, and $\mathrm{Cu}$ separate near base; with two $\mathrm{m}$-cu crossveins; five apical cells, the third peciolate. Wings with four apical cells; $\mathrm{r}-\mathrm{m}$ crossvein present.

Male. Similar, just smaller. Aedeagus slightly compressed at apex, projected dorso-laterally in a short spine; styles truncate, slightly expanded apically.

Material examined. Holotype female labeled "Portachuelo, 3300/ m. Tovar. MERIDA/ VENEZ. Bordón/ leg. 15 III 1978". Paratypes: 36 females and 29 males from VENEZUELA, various localities of Aragua, Merida, Tachira and Trujillo; all collected by C. Bordón. The holotype and 1 paratype are deposited in the Collection Pe. J.S. Moure, Departamento de Zoologia, Universidade Federal do Paraná; remainder paratypes in the Bordón's Collection.

Comments. This species resembles Acutalis fusconervosa Fairmaire. However, it is more robust and the venation of tegmina is different, presenting two $\mathrm{m}$-cu crossveins (with discoidal cell M). The third apical cell is almost always larger than the fifth. The aedeagus presents only two dorso-lateral spines and the styles are truncate at apex.

\section{Bordonia clypeata sp.n.}

Figs 13-14, 29

Diagnosis. Head convex, with clypeus prominent. Pronotum yellowishbrown, low, convex, roughly punctate.

Measurements (in mm). Female/male: Total length 6.20/5.68; length of pronotum 5.40/4.80; width of head 2.08/2.04; width between humeral angles $2.40 / 2.40$.

Description. Holotype female. Pronotum yellowish-brown, pale anteriorly; undersurface of body black. Head punctate as pronotum, more or less shining, triangular, about three times wider than long; superior margin sinuous; eyes ovate, 
not produced laterally; ocelli situated on an imaginary line that passes through center of eyes, nearer to eyes and superior margin than to each other; supra-antennal ledges with margins slightly sinuous and with contour line continuing with that of clypeus; clypeus rounded, in frontal view as wide as long, somewhat prominent and presenting along the inferior border a distinct carina. Pronotum low, convex, roughly punctured, extended posteriorly to about the extreme point of fifth apical cell of tegmina; median carina practically absent, just in form of a smooth line; lateral margins, after humeral angles, distinctly impressed longitudinally. Tegmina with $\mathrm{R}, \mathrm{M}$, and $\mathrm{Cu}$ separate near base; with two m-cu crossveins; five apical cells, the third peciolate. Wings with four apical cells; $r-m$ crossvein present.

Male. Similar, just smaller. Clypeus and body black. Tegmina darkened toward apex. The aedeagus is like that of A. fusconervosa Fairm. but the styles, on the other hand, are not strongly recurved.

Material examined. Holotype female labeled "Cuesta Boba, 3500/m. SANTANDER/ COL.[ombia] Bordón/ leg. 8 III 1983". Paratypes: 1 female with same label data; 3 males from" Volcán Coto-/paxi, m 4000" "ECUAD.[or] Bordón/ leg. 30 XII 1971". There are also two nymphs (pinned; probably 4-5th instar). The holotype and 1 paratype are deposited in the Collection Pe. J.S. Moure, Departamento de Zoologia, Universidade Federal do Paraná; remainder paratypes in the Bordón's Collection.

Comments. This species resembles $B$. virescens (Funkhouser) mainly because of its rough punctures; the shape of clypeus however, is very different, markedly prominent and presenting a distinct carina along the inferior border.

\section{Bordonia majuscula sp.n.}

Figs $15-16,30$

Diagnosis. Robust. Head and pronotum smooth, shining, yellowish-brown. Post-ocular lobule with a distict carina close to eyes.

Measurements (in mm). Female/male: Total length 8.40/8.00; length of pronotum 7.00/6.68; width of head 2.92/2.80; width between humeral angles 3.32/3.08.

Description. Holotype female. Pronotum yellowish-brown; undersurface of abdomen black. Head smooth, shining, triangular, about three times wider than long; superior margin sinuous; eyes ovate, not produced laterally; ocelli situated on an imaginary line that passes through center of eyes, equidistant from each other and to eyes and nearer to superior margin; supra-antennal ledges with margins slightly sinuous and with contour line continuing with that of clypeus; clypeus normal, in frontal view wider than long, apex slightly trilobate. Pronotum low, convex, finely punctured, smooth and brilliant, extended posteriorly to about the extreme point of fifth apical cell of tegmina; median carina practically absent, just in form of a smooth line; lateral margins, after humeral angles, distinctly impressed longitudinally. Tegmina with $\mathrm{R}, \mathrm{M}$, and $\mathrm{Cu}$ separate near base; with two m-cu crossveins; five apical cells, the third peciolate. Wings with four apical cells; r-m crossvein present. 

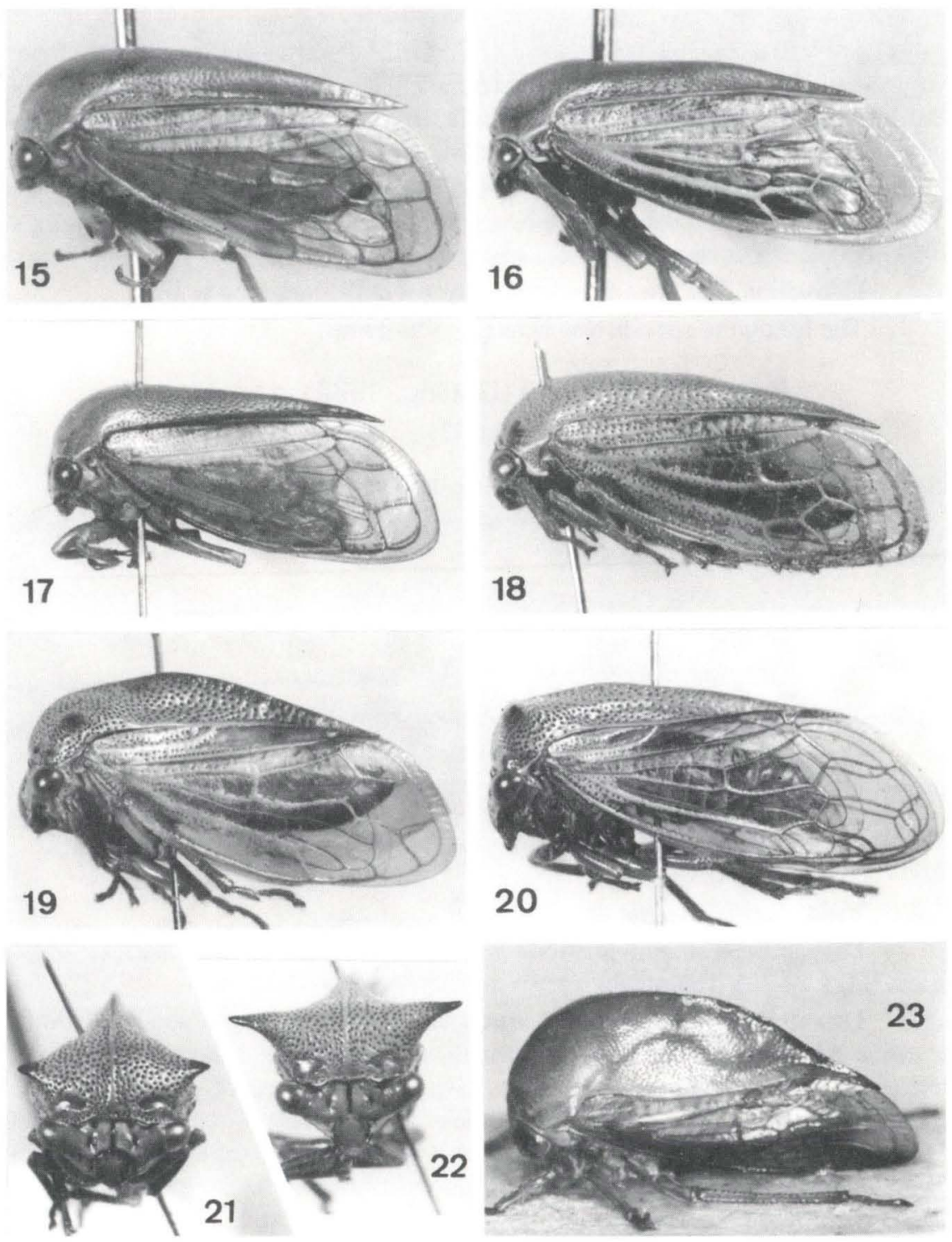

Figs 15-23. (15) Bordonia majuscula sp.n., Holotype female; (16) idem, male; (17) Bordonia nigricosta; (18) Bordonia virescens; $(19,21)$ Cornutalis cauca sp.n., Holotype female; $(20,22)$ Cornutalis valida sp.n., Holotype male; (23) Eumela darnioides, Holotype.

Male. Similar, just smaller, with undersurface of body black. The aedeagus is similar to that of $B$. clypeata, just more elongate and less curved; the styles are curved in almost right angle and with the external angle of apex acute.

Material examined. Holotype female labeled "Portachuelo, 3300/ m. Tovar, 
MERIDA/VENEZ[uela]. Bordón/leg. 15 III 1978". Paratypes: 1 female and 1 male with same label data. The holotype and 1 paratype are deposited in the Collection Pe. J.S. Moure, Departamento de Zoologia, Universidade Federal do Paraná; the other paratype is in the Bordón's Collection.

Comments. This species is very similar to B. venezuelana, differing by the more robust size; the post-ocular lobules are somewhat elongate and presenting a well marked carina along the border beside the eyes.

Derivation. The specific name is allusive to the larger body size.

The following species also belong to this genus:

\section{Bordonia nigricosta (Goding, 1926), comb.n.}

(Fig. 17)

Thrasymedes nigricosta Goding, 1926: 109 (Type loc.: Ecuador). -Metcalf \& Wade, 1965: 1154.

Comments. This species is very similar to $B$. venezuelana differing only by the black costal margin of tegmina.

\section{Bordonia virescens (Funkhouser, 1940), comb.n.}

\section{Fig. 18}

Thrasymedes virescens Funkhouser, 1940: 288 (Type loc.: Peru). -Metcalf \& Wade, 1965: 1156.

Comments. This species is distinguished by the rough punctuation of the pronotum; because of it, the surface is less brilliant.

\section{Cornutalis gen.n.}

Type species: Cornutalis cauca sp.n.

Diagnosis. Pronotum tectiform with supra-humeral horns; posterior process acute (Figs 19-22). Tegmina with two m-cu crossveins.

Description. Head triangular, smooth and obliquely striate, about two times as wide as long; superior margin sinuous; supra-antennal ledges more or less triangular, with margins almost straight. Clypeus rounded or oval, slightly convex. Eyes ovate, projected laterally. Ocelli more or less equidistant from each other and to eyes and nearer to superior margin. Pronotum tectiform, roughly punctate, with two supra-humeral processes; extended posteriorly to about the middle of fifth apical cell, terminating in an acute point; lateral margins more or less impressed; median carina well marked. Tegmina entirely exposed; veins $\mathrm{R}, \mathrm{M}$, and $\mathrm{Cu}$ separate near base, with two m-cu crossveins (one discoidal cell $\mathrm{M}$ ); five apical cells, the third peciolate. Wings with four apical cells; $r-m$ crossvein present.

Comments. The shape of pronotum, in this genus, resemble that of Ceresa A. \& S., presenting two supra-humeral horns and a more or less tectiform posterior process, which is close to the tegmina and terminating in a sharp point. The venation of tegnmina is similar to that of Bordonia, described herein, with one discoidal cell.

Derivation: the generic name is a combination of Cornu (=horn) with talis (=similar). 


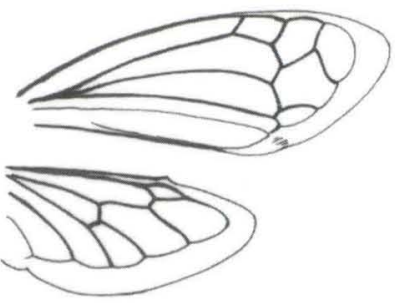

\section{4}
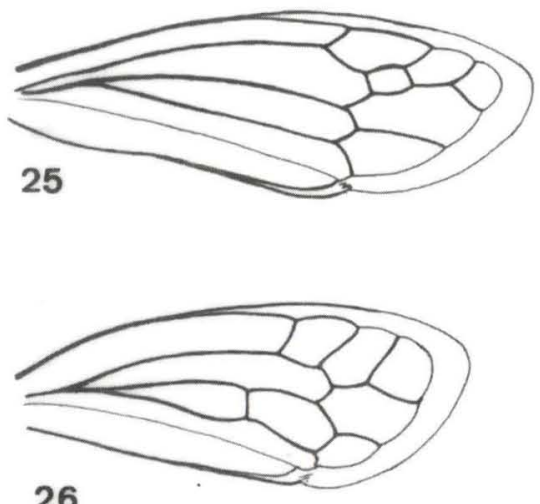

26

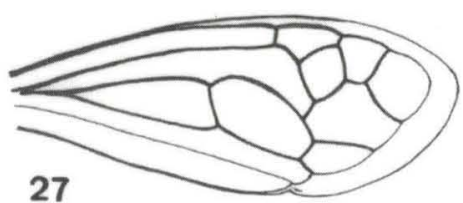

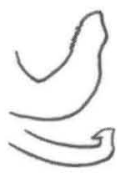

28

30

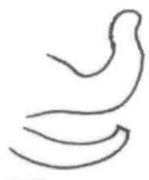

29

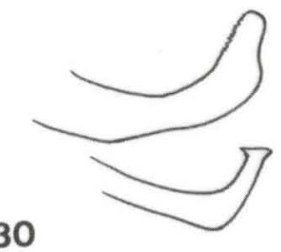

31

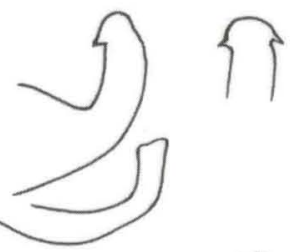

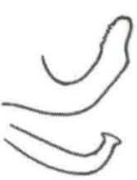

32

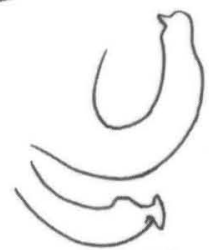

33

Figs 24-33. Tegmina, wing and genitalia. (24) Acutalis; (25) Thrasymedes; (26) Bordonia; (27) Euritea; (28) Acutalis fusconervosa; (29) Bordonia clypeata sp.n., Paratype; (30) Bordonia majuscula sp.n., Paratype; (31) Bordonia venezuelana sp.n., Paratype (with detail of apex of edeagus, in dorsal view); (32) Bordonia virescens; (33) Cornutalis valida sp.n., Holotype.

\section{Cornutalis cauca sp.n.}

Figs 19-21

Diagnosis. Pronotum caramel-yellow with apex of supra-humeral horns and posterior process, dark-brown; supra-humeral horns short; posterior process tectiform.

Measurements (in mm). Female. Total length 8.40; length of pronotum 6.48; width of head 2.84; distance between tips of supra-humeral horns 3.56 .

Description. Holotype female. Pronotum caramel-yellow, roughly punctured, the bottom of which black; apex of supra-humeral horns, posterior process along 
median carina, including apex, dark-brown; tegmina yellowish-amber; abdomen ventrally darkened. Head triangular, about two times wider than long, slightly convex and obliquely striate; superior margin sinuous; eyes ovate, produced laterally; ocelli situated below an imaginary line that passes through center of eyes, equidistant from each other and to eyes and nearer to superior margin; supra-antennal ledges more or less triangular, with margins almost straight. Clypeus more or less rounded, convex. Pronotum relatively low, metopidium convex; supra-humeral processes short, sub-conical, slightly flatened dorso-ventrally, almost horizontal; posterior process distinctly tectiform, median carina well marked, lateral margins slightly impressed, extended to about middle of fifth apical cell of tegmina, terminating in an acute point. Tegmina with $\mathrm{R}, \mathrm{M}$, and $\mathrm{Cu}$ separate near base; with two m-cu crossveins; five apical cells, the third peciolate. Wings with four apical cells; r-m crossvein present.

Male. Unknown.

Material examined. Holotype female labeled "P. N. Puracê/ volcán PURACE, m./ 3700. Dto. CAUCA" "COL.[OMBIA]. Bordón leg./ 21 XII 1971". The holotype is deposited in the Collection J.S. Moure, Departamento de Zoologia, Universidade Federal do Paraná.

Comments. This species presents short supra-humeral horns (though the male is not known), almost horizontal and sub-conical. The posterior process is tectiform and with a well marked dorsal carina.

Derivation. Locality name in apposition.

\section{Cornutalis valida sp.n.}

Figs $20,22,33$

Diagnosis. Pronotum caramel-yellow with tips of supra-humeral horns and posterior process, black; supra-humeral horns robust.

Measurements (in mm). Female/Male. Total length 9.68/9.00; length of pronotum 7.80/7.20; width of head 3.28/2.96; distance between tips of supra-humeral horns 4.60/4.60.

Description. Holotype male. Pronotum caramel-yellow with tips of suprahumeral horns and posterior process, black; roughly punctured with the bottom of which black; tegmina yellowish-amber; abdomen darkened. Head triangular, two times wider than long, slightly convex and obliquely striate; superior margin sinuous; eyes ovate, produced laterally; ocelli situated below an imaginary line that passes through center of eyes, equidistant from each other and to eyes and nearer to superior margin; supra-antennal ledges more or less triangular, impressed, with margins almost straight. Clypeus more or less ovoid, convex, apex antero-posteriorly flattened. Pronotum relatively low, metopidium convex; supra-humeral processes long, about twice as long as wide basally, conical, almost horizontal in front view, and slightly recurved seen from above; posterior process more or less slender, distinctly tectiform, median carina well marked, lateral margins slightly impressed, extended to about middle of fifth apical cell of tegmina, terminating in a sharp point. Tegmina with $\mathrm{R}, \mathrm{M}$, and $\mathrm{Cu}$ separated near base; with two m-cu crossveins; five 
apical cells, the third peciolate. Wings with four apical cells; r-m crossvein present. Male pygofer distinct; subgenital plate elongate, apically rounded and notched; aedeagus subcilindrical, strongly curved upward, with two minute spines dorso-apically; styles truncate, twisted at apex.

Female. Very similar.

Material examined. Holotype male labeled "Carret. Quito-Sto./ Domingo, m. 2700" "ECUAD.[OR]. Bordón/ leg. 28 V 1972". Paratype: 1 female "Ecuador: Napo/ N. Papallacta, 4100 m/ 14.II.1983/ leg. Littuggert".

The holotype is deposited in the Collection J.S. Moure, Departamento de Zoologia, Universidade Federal do Paraná. The paratype in the collection of Lunds Universitets, Sweden.

Comments. This species, in comparison with the former, presents strong supra-humeral horns (though the female is not known). The posterior process is more slender.

Derivation. The specific name is allusive to the stout supra-humeral horns.

\section{Species transferred to other tribes}

\section{Smiliinae, Ceresini}

Tapinolobus curvispina (Walker), comb.n.

Parmula curvispina Walker, 1858: 152

Boethoos curvispina; Funkhouser, 1927: 304

Thrasymedes curvispina; Metcalf \& Wade, 1965: 1154

Tapinolobus fasciatus Sakakibarà, 1969: 596. - Kopp \& Yonke, 1979: 17. Syn.n.

\section{Darninae, Cymbomorphini}

\section{Eumela darnioides (Walker), comb.n.}

Fig. 23

Thelia darnioides Walker, 1858: 140. - Broomfield, 1971: 344.

Euritea darnioides; Metcalf \& Wade, 1965: 1143.

\section{REFERENCES}

BaLl, E.D. 1905. Some new Homoptera from the South and Southwest. Proc. Biol. Soc. Washington 18: 117-120.

BRoOMFIELD, P.S. 1971. A Catalogue of the membracid types (Homoptera: Membracidae) in the British Museum (Natural History). Bull. British Museum (Natural History). Entomology 25 (8): 327-386.

BuckTON, G.B. 1903. A Monograph of the Membracidae. London, L. Reeve \& Co. Lmtd., 296p.

CALDWELl, J.S. 1949. A generic revision of the treehoppers of the tribe Ceresini in America North of Mexico, based on a study of the male genitalia. Proc. U.S. Nat. Mus. 98 (3234): 491-521. 
DEITZ, L.L. 1975. Classification of the higher categories of the New World treehoppers (Homoptera,Membracidae). North Carolina Agr. Exp. Sta. Tech. Bull. 225: $1-177$.

Fairmaire, L.M.H. 1846. Revue de la tribu des Membracides. Ann. Soc. Ent. France 4: 235-320.

FowLER, W.W. 1895. Order Rhynchota; Suborder Hemiptera-Homoptera. (cont.).

Biol. Centr. Amer. 2: 89-112.

FunkHouser, W.D. 1927. General Catalogue of the Hemiptera. Fasc. 1. Membracidae. Raleigh, North Carolina State College, 581p.

. 1940. New Peruvian Membracidae (Homoptera). Jour. N.Y. Ent. Soc. 48: 275-293.

Goding, F.W. 1926. New genera and species of Membracidae (Homoptera). Trans. Amer. Ent. Soc. 52: 103-110.

KIRKALDY, G.W. 1904. Bibliographical and nomenclatorial notes on the Hemiptera. No. 2. The Entomologist 37: 279-283.

KopP, D.D. \& T.R. YONKE. 1973. The treehoppers of Missouri: Part 2. Subfamily Smiliinae; Tribes Acutalini, Ceresini, and Polyglyptini (Homoptera: Membracidae). Jour. Kansas Entomol. Soc. 46 (2): 233-276.

Kopp, D.D. \& T.R. YonKE. 1979. A taxonomic review of the tribe Ceresini (Homoptera: Membracidae). Miscell. Publ. Ent. Soc. Amer. 11 (2): 1-97.

MetCALF, Z.P. \& V. WADE. 1965. General Catalogue of the Homoptera. Membracoidea. Sec. 1-2. Raleigh, North Carolina State University, 1552p.

SAKAKIBARA, A.M. 1969. As espécies brasileiras de Stictolobus Metcalf e descrição de um novo gênero correlato (Homoptera -Membracidae). Rev. Brasil. Biol. 29 (4): 589-600.

SAY, T. 1830. Description of new North American Hemipterous insects, belonging to the first family of the section Homoptera of Latreille. Jour. Acad. Nat. Sci. Phil. 6: 235-244.

STÅL, C. 1862. Bidrag till Rio Janeiro-traktens Hemipter-fauna. II. Ofversigt Svenska Vetensk. Akad. Förhandl. 3 (6): 1-75. . 1864. Hemiptera Mexicana enumeravit speciesque novas descripsit. Stett. Ent. Ztg. 25: 49-86.

1867. Bidrag till Hemipterernas Systematik. Ofvers. Kongl. Vetensk. Förhand. 7: 491-560.

- 1869. Hemiptera Fabriciana. Svensk. Vetensk. Akad. Handl. 8: 18-58.

TSAI, J.H. \& D.D. KopP. 1980. Life history, morphology, and taxonomy of Acutalis tartarea (Say) (Homoptera: Membracidae).

WALKER, F. 1851. List of the Specimens of Homopterous Insects in the Collection of the British Museum. London, British Museum, Part 2, p.261-636. - 1858. Homoptera. Insecta saundersiana; or characters of undescribed insects in the collection of William Wilson Saunders, Esq.. London, 117p.

Recebido em 07.XI.1996; aceito em 05.IX.1997. 